світ навколо. Згадаймо, «безкрая палюча жовтизна різала очі...» («Син»). А чого варте поєднання в творах, особливо в «Сині», двох кольорів жовтого і червоного - «жовтий мертвий степ», «весь світ брався в його очах червоними, страшними колами...». У живописних символах поєднання жовтого i червоного кольорів символізує пекло, жах, божевілля. Саме туди потрапляє Васюренко ще за життя, бо в хаті «сморід», «серце затіпалося млосно, стискуючись у безнадії й заздрості», «навіть коники не сюрчали, не літала мушва»- самотність і порожнеча. Картина пекла, змальована художником слова.

\title{
Література:
}

1. Мельник В.О. Валер'ян Підмогильний. - К.: «Знання», 1991 - 48 с.

2. Ніцше Фрідріх. Так казав Заратустра. - К.: «Основи», «Дніпро», $1993-414$ c.

3. Українське слово. Хрестоматія української літератури та літературної критики ХХ ст., кн. 2. - К.: «Рось», 1994 - 718 с.

DOI https://doi.org/10.30525/978-9934-26-004-9-32

\section{ОСНОВНІ ФОРМИ ТА МЕТОДИ ІДЕОЛОГІЧНОГО КОНТРОЛЮ ВЛАДИ В ГАЛУЗІ КУЛЬТУРИ В УКРАЇНІ (40-50-ТІ РОКИ ХХ СТ.)}

\author{
Сірук Н. М. \\ кандидат історичних наук, \\ дочент кафедри документознавства та інформаційної діяльності \\ Редчук Р. О. \\ кандидат педагогічних наук, \\ доиент кафедри документознавства та інформаиійної діяльності \\ Приватного вищого навчального закладу \\ «Академія рекреаційних технологій та права» \\ м. Луцьк, Україна
}

В сучасних умовах, в період незалежної Української держави, особливого значення набуває відродження національної історичної пам'яті. У зв'язку з цим значний науковий i пізнавальний інтерес становить дослідження духовного життя в Україні другої половини 40-х - початку 50-х років XX ст., зокрема ідеологічного контролю 
сталінського режиму за культурою і наукою, за творчою діяльністю та науковим пошуком інтелігенції. Ці проблеми знайшли певне відображення в науковій літературі, проте українська історіографія все ще перебуває на етапі вивчення механізмів політичного контролю тоталітарної держави за культурно-науковою сферою. Будуючи українську державу ми маємо також віддати шану пам'яті тисячам безневинних жертв, які на своїх плечах винесли неймовірні труднощі i тим самим сприяли збереженню національної самобутності українського народу та його культури.

Державотворчі процеси кінця XX - початку XXI ст. значно активізували інтерес до вивчення післявоєнної історії України - останнього періоду сталінщини, так званої «ждановщини» [1, с. 78]. Відновлення ідеологічного тиску на суспільство було довірено А. Жданову - секретарю з ідеології, близькому помічникові Й.Сталіна. «Ждановщина» позначилася боротьбою проти «безідейності, безпринципності, формалізму, космополітизму й низькопоклонства перед гнилим Заходом». На практиці вона швидко перетворилася на російський шовінізм і викликала черговий погром культури неросійських народів; зокрема зазнала переслідування єврейська національна культура в СССР. В Україні «ждановщина» набрала форм гострої критики «буржуазного націоналізму»- в культурі, мистецтві, історії та літературі, розкритиковано твори письменників, композиторів. Партійна лінія «ждановщини» вимагала від українських культурних діячів, щоб українська культура «тісніше зливалась 3 великою російською» [2, с. 666].

Почалися планомірні, періодичні, викривальні ідеологічні кампанії, які були спрямовані насамперед проти інтелігенції, проти тих, хто прагнув лібералізації культурної атмосфери та цілковитого послуху серед них. Духовне життя суспільства було поставлене під жорсткий контроль, що заважало розвитку літератури, театру, кіно та мистецтва загалом, які і стали першими об'єктами нападок останнього періоду сталінщини. Сфера ідеології розглядалась як «ідеологічний фронт», головні удари на якому направлялись проти «українського буржуазного націоналізму», проти відступів від «марксизму-ленінізму» в літературі та мистецтві [3, с. 73-80].

В другій половині 1940-х - на початку 1950 -х років вийшла низка постанов ЦК КП(б)У (близько 12), присвячених питанням літератури та мистецтва, які стали складовою частиною ідеологічних кампаній, відомих під назвою «ждановщини». Вістря партійної критики було спрямовано на подолання самобутнього національного змісту, особливого національного колориту української літератури та мистецтва, на «викриття українського буржуазного націоналізму». Одним 3 126 
головних завдань радянського керівництва було належне ідейне спрямування літературно-мистецької творчості, яка відповідала б пануючій марксистсько-ленінській ідеології i виконувала б певні функціональні завдання - політичні, виховні та ін. Цій меті підпорядковувалась діяльність відповідних підрозділів партійного апарату, органів цензури, творчих спілок, зокрема Спілки радянських письменників і Спілки радянських композиторів, що стали суттєвим елементом у системі управління літературою та мистецтвом. Творчі спілки втілювали в життя принцип партійності літератури і пропагували метод соціалістичного реалізму, що служив засобом внутрішнього контролю за творчим процесом.

Партійні документи широко коментувались у редакційних i авторських статтях, у виступах на численних зборах працівників культури та мистецтва. У них давалась спотворена оцінка духовного життя в республіці, висувалися надумані й необгрунтовані звинувачення на адресу провідних письменників та митців. Особливо гострої критики за так звані ідейні прорахунки зазнали О. Довженко, I. Сенченко, М. Рильський, Ю. Яновський, В. Сосюра, І. Вільде та інші. За звинуваченнями в «буржуазному націоналізмі» виключено зі Спілки радянських письменників України П. Карманського, М. Рудницького, А. Патрус-Карпатського. На певний час в доробку багатьох митців запанувало псевдооптимістичне відтворення дійсності, кон'юнктурне відображення суспільного життя, внаслідок чого велика кількість тем, гострих проблем залишилась поза увагою тодішньої літератури.

Влада тримала під жорстким контролем також засоби масової інформації. Діяльність газет i журналів визначалася ідеологічною заангажованістю, що негативно впливало на культурні процеси в Україні. На вимогу партійних органів преса нерідко грубо й безапеляційно оцінювала доробок літераторів та митців, порушувала елементарні права свободи творчості. Редакції газет та журналів практично змагалися у виявленні митців, які своєю творчістю «паплюжать ім'я радянського інтелігента», iз завзяттям «розвінчували» їх погляди. Положення редакційних статей всесоюзних та республіканських газет, всі настанови та рекомендації вважалися беззаперечними, бо походили 3 найвищої інстанції. Все, що друкувалося в центральній пресі, розглядалося на місцях як остаточний вердикт, який не підлягав оскарженню.

Значного ідеологічного тиску зазнало театральне та музичне життя республіки. Обов'язковим для репертуару стало переважання вистав на сучасні теми, які б оспівували пафос соціалістичного творення, будівничу енергію радянських людей. Згідно з партійними постановами, основним завданням мистецького життя в Україні другої половини 40-х - початку 50-х років XX ст. повинно було стати активне 
пропагування політики радянської держави, здобутків УРСР у різних сферах економічного, соціального, духовного розвитку, оспівування братерства українського народу з російським народом.

Отже, основними формами та методами політико-ідеологічного контролю влади у галузі літератури та мистецтва були:

- утвердження принципу партійності літератури та мистецтва, жорсткого підпорядкування їх партійній справі;

- встановлення диктатури одного стилю - соціалістичного реалізму, що змушував митців пропагувати ідеали соціалізму, радянський спосіб життя;

- нав'язування єдиного ідеологічного підходу, в тому числі так званого пролетарського інтернаціоналізму, за яким приховувалась русифікація національних культур;

- жорстка критика найменших відступів від політико-ідеологічних канонів, насамперед проявів «національної обмеженості», «буржуазного націоналізму»;

- ухвалення постанов ЦК ВКП(б) і ЦК КП(б)У в ділянці літератури та мистецтва, які ставали засобом впливу на громадську свідомість, «регулювання» творчого процесу [4, с. 107];

- здійснення «соціального замовлення» в духовній сфері, визначення тематики літературних і мистецьких творів, репертуарів драматичних i музичних театрів;

- регламентація стильових прийомів, образних пошуків, літературномистецьких форм, які трактувалися як невід'ємний елемент цілісного ідейно-політичного сприйняття того чи іншого твору;

- діяльність творчих спілок, які постійно тримали в полі зору не тільки творчість, але й щоденне життя діячів літератури та мистецтва, відомих майстрів і здібних початківців (замовлення на твори, визначення тематики, рецензування рукописів, публікація праць, заохочення політичного конформізму, матеріальне і моральне стимулювання);

- діяльність органів цензури, що здійснювали ретельний нагляд за ідейно-політичним змістом літературних та мистецьких творів, їх відповідністю ідеологічним нормам (вичитка рукописів, робота 3 авторами, ідеологічне «наставництво», інформування партійних органів про всі випадки ідейно-політичних «відступів», не тільки попередній - в рукописах, але й наступний контроль - уже виданих творів);

- вирішення кадрових питань в галузі літератури і мистецтва, призначення на керівні посади перевірених партійних «бійців», у тому числі в західних областях України - працівників зі східного регіону республіки [4, с. 107-108].

Система прагнула цілковито підпорядкувати своєму впливові культуру та мистецтво, спрямувати їх у відповідне політичне й 128 
ідеологічне русло, регламентувати найрізноманітніші прояви творчої активності та інтелектуального пошуку. Втручання режиму вело до деформації творчості митця, література і мистецтво були найважливішими i найдієвишими каналами формування культу особи Й. Сталіна. Однак і в такому важкому стані, попри всі труднощі, «проробки» і гоніння, митцям вдалось зберегти своє творче обличчя, створити цікаві самобутні твори, які стали відомими далеко за межами республіки.

\section{Література:}

1. Баран В.К. Україна: новітня історія (1945-1991 р.р.). - Львів, 2003. $-670 \mathrm{c}$.

2. Енциклопедія українознавства: Загальна частина. Т. 2 / Ред. В. Кубійович, З. Кузеля (репринтне відтворення). - Київ, 1994. - 800 с.

3. Замлинська О. Ідеологічний терор та репресії проти творчої інтелігенції у перші повоєнні роки (1945-1947рр.). // Київська старовина. - 1993. - № 2. - С. 73-80.

4. Сірук Н.М. «Ждановщина» в Україні (друга половина 40-х початок 50-х років XX ст.): монографія / Н. М. Сірук. - Луцьк, 2013. $206 \mathrm{c}$.

DOI https://doi.org/10.30525/978-9934-26-004-9-33

\section{«БУДИНОК «СЛОВО»: ДОКУМЕНТАЛЬНА ХРОНІКА РОЗКВІТУ ТА ТРАГЕДІЇ МОДЕРНОЇ УКРАЇНСЬКОЇ КУЛЬТУРИ}

\section{Томенко О. М.}

кандидат філологічних наук, доцент кафедри культури та соціально-гуманітарних дисциплін Національної академії образотворчого мистецттва і архітектури м. Київ, Україна

Дослідження доби «Розстріляного Відродження» - потужного українського мистецького руху - розпочалося ще в 1990-х роках минулого століття. Одним із перших почав вивчати твори та архіви (українські та закордонні) академік Микола Жулинський [2]. За цей час було захищено багато дисертацій, видано твори та монографії, присвячені представникам «Розстріляного Відродження», їхні імена внесені до шкільної програми. Але лише у 2017 році вийшов на екрани 